\title{
Growth Hormone Deficiency - A Case Report
}

\author{
Devkota $A^{1}$, Upadhyay $S^{2}$ \\ ${ }^{1}$ Dr. S. Devkota', MBBS, Medical Officer, ${ }^{2}$ Dr. Satyam Upadhyay, MBBS. MD, Lecturer. Both from the Department of \\ Paediatrics, Nepal Medical College and Teaching Hospital, Jorpati, Kathmandu, Nepal.
}

Address of correspondence: Dr. Satyam Upadhyay, E-mail: satyam85@hotmail.com

\begin{abstract}
Growth hormone is an anabolic hormone released in pulsatile manner in the circulation. It is one of the uncommon causes of short stature in children and is largely idiopathic. The case report is about a 12 years old boy who presented with short stature. He was diagnosed to have Growth hormone deficiency. Growth hormone was started after diagnosis was made.
\end{abstract}

Key words: Growth hormone, pituitary.

\section{Introduction}

Growth hormone has a well-defined role in promoting childhood growth and in maintaining normal adult body composition. Growth Hormone deficiency can be isolated or associated with pituitary disturbances ${ }^{1}$. Epidemiological studies suggest that idiopathic isolated growth hormone deficiency occurs more frequently than multiple pituitary hormone deficiency in children whereas in adult onset $\mathrm{GH}$ deficiency is frequently due to pituitary adenomas, surgeries and irradiation ${ }^{2}$. Synthetic human growth hormone (somatropin) shows improvement in children with isolated cases of growth hormone deficiency if started early provided that it should be administered under strict supervision.

\section{The Case}

A 12 year old male presented to Nepal Medical College Teaching Hospital in April, 2008 with the complaints of not gaining height and weight. There was no history of perinatal insult, constitutional delay or history suggestive of any systemic causes of short stature. Birth weight and length were adequate and according to race. Dentition was however delayed. On examination the boy was alert with stable vitals and no abnormalities detected in systemic examination. There was no signs of dysmorphism. The anthropometric measurements showed; weight-18 kgs and height 110 $\mathrm{cms}$. His height for age was below $3^{\text {rd }}$ percentile ( $\mathrm{NCHS}$ ) i.e. $73 \%$ of an expected (height age: $51 / 2$ years) and weight for age was also below $3^{\text {rd }}$ percentile (NCHS) i.e.
$45 \%$ of an expected (weight age: 5 years). However his weight for stature was between $25^{\text {th }}$ and $50^{\text {th }}$ percentile (NCHS). The mid parental height was $158.25 \mathrm{cms}$. Head circumference was $50 \mathrm{~cm}$. The ratio of upper and lower segment and arm span suggested to be proportionate short stature. Growth velocity was less than $4 \mathrm{~cm} /$ year. Penile length was $2.5 \mathrm{~cm}$ and there were no secondary sexual characteristics.

Investigations showed no abnormalities in routine blood, stool and urine examinations. The blood glucose, renal function test, liver function test and thyroid function tests were all normal. No abnormalities were present in the chest X-ray. However, his bone age was delayed (Bone age: 7 years). Clonidine stimulation test (Growth hormone assay) was done which was consistent with Growth hormone deficiency. Hormone binding factors were found to be within normal limits. Pituitary gland was unremarkable on MRI study.

Growth hormone (Genotropin) 1.5 Units was started subcutaneously, once daily, 5 days in a week in the patient along with Calcium. Growth hormone was to be continued till final height was reached. A reasonable approach to stop Growth hormone therapy is to assume that near final height is reached in boys by the age 16 . Regular follow-up was advised so that frequent blood glucose levels and thyroid hormonal assay could be monitored. There was a significant increase in his height on follow up after a year and the height velocity was 11 cms following growth hormone therapy. (Fig. 1) 


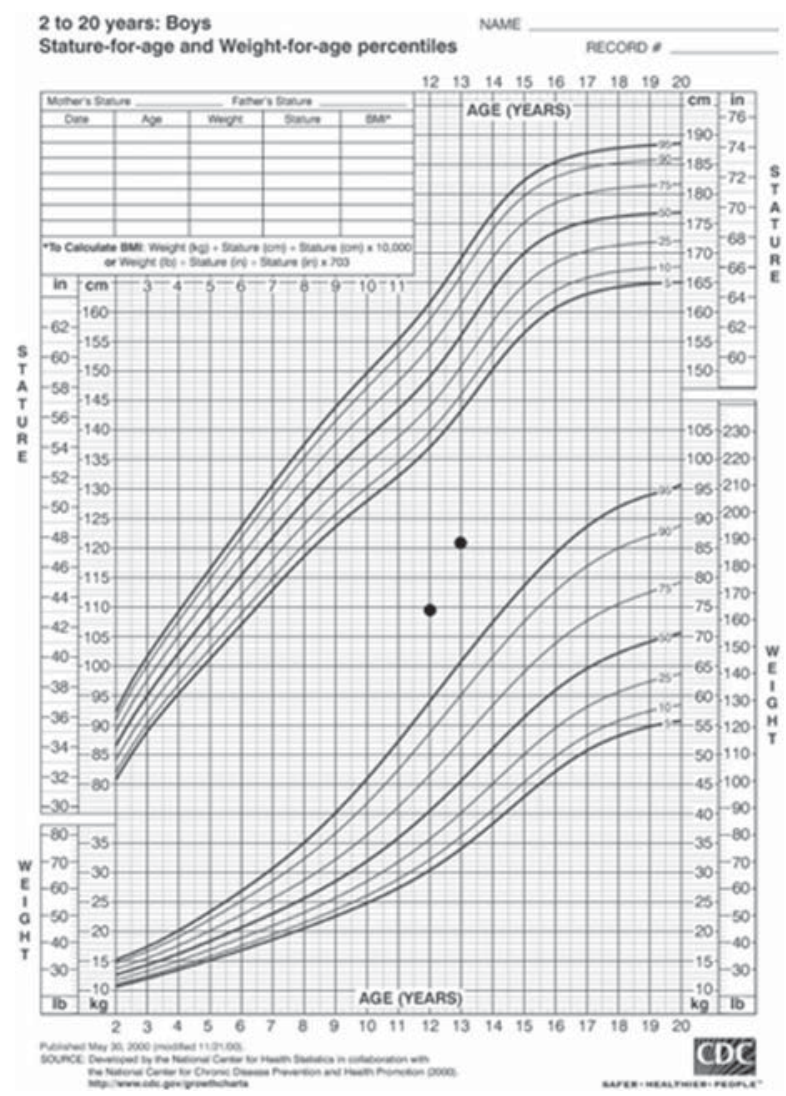

Fig 1: Growth chart showing increase in height after Growth hormone therapy

\section{Discussion}

Natural growth hormone is released in a pulsatile manner from the adenohypophysis spontaneously and in response to various physiologic stimuli ${ }^{6}$. Its production is stimulated by growth hormone-releasing factor and inhibited by somatostatin, which are both produced by the hypothalamus. Growth hormone binds to receptors on hepatic tissue and other cells, stimulating the production of insulin-like growth factor-I either locally or at the site of growing bone. Growth hormone binds to a specific growth hormone-binding protein (GHBP) and circulates. This GHBP is the extracellular portion of the growth hormone receptor. IGF-1 binds to one of several IGF-binding proteins (IGFBPs) and circulates almost entirely (>99\%) in the bound state. IGFBP3 accounts for most of the IGF-I binding and this binding protein directly depends on growth hormone ${ }^{5,7}$. Growth hormone deficiency is an uncommon cause of short stature. In one study done in England and Wales, the approximate incidence of growth hormone deficiency was only 1 in every 30,000 births, about half of the patients had idiopathic deficiency and half had deficiency secondary to intracranial disease. These patients with low serum growth hormone levels associated with maternal deprivation were excluded ${ }^{4}$. Several cases apart from being idiopathic causes for a growth hormone deficiency could be due to CNS tumors including (craniopharyngiomas) and malformations ${ }^{7}$ perinatal trauma, lack of oxygen at birth ${ }^{3,8}$, Septo-optic dysplasia $^{3,7}$, Leukemias, CNS trauma, CNS radiation ${ }^{7}$, abnormalities in the hormone receptors and very rarely it may be due to a genetic defects, which in some instances may also be heredity. Children with GHD usually present with short stature and a low growth velocity for age and pubertal stage. Alternative causes of poor growth needs to be considered and excluded. Age at presentation can vary from the first few months of life to adolescence. Typically the $\mathrm{GH}$-deficient child has increased subcutaneous fat especially around the trunk. The face is immature with a prominent forehead and depressed midfacial development; this is related to the lack of $\mathrm{GH}$ effect on endochondral growth at the base of the skull, occiput, and the sphenoid bone. Dentition is delayed. In males the phallus may be small, and the average age of pubertal onset is delayed in both boys and girls ${ }^{3}$. Radiograph shows bone age lower than the chronological age. Growth hormone levels and binding protein levels (IGF-I and IGFBP-3) will show whether the growth problem is caused by a problem with the pituitary gland. MRI of the head can show the hypothalamus and pituitary glands ${ }^{9,10}$. Treatment with growth hormone will usually result in marked acceleration of linear growth. This is most pronounced in the first two years of therapy. In one study of more than 12,000 children, growth hormone replacement therapy was started at an average age of $9.2 \pm 4.1$ years and produced an increase in growth velocity from $4.4 \mathrm{~cm}$ per year to 10.0 $\mathrm{cm}$ per year. The younger the patient at the initiation of treatment and the more severe the growth deficiency, the better the response to early therapy ${ }^{5}$.

\section{References}

1. Jenkins RC, Ross RJ. Growth hormone therapy for protein catabolism. QJM 1996;89:813-9.

2. Hindmarsh PC, Swift PGF. An assessment of growth hormone provocation tests. Arch Dis Child 1995;72:362-36.

3. Shalet SM, Toogood A, Rahim A, Brennan BMD. The Diagnosis of Growth Hormone Deficiency in Children and Adults. Endocr Rev 1998:19(2):20323.

4. Parkin JM. Incidence of growth hormone deficiency. Arch Dis Child 1974;49:904-5.

5. Jeffrey T, Kirchner DO, Vance ML, Mauras N. Growth hormone therapy in adults and children. N Engl J Med 1999;341:1206-15. 
6. Prinz PN, Weitzman ED, Cunningham GR. Plasma Growth Hormone during Sleep in Young and Aged Men. J Gerontol 1983;38:519-24.

7. Stephen Kemp: Pediatric Growth Hormone Deficiency Updated: Sep 15, 2008. Accessed Feb 2011. Available from http://emedicine.medscape. com/article/923688.

8. Green S. Growth hormone deficiency. Accessed Feb 2011, Available from http://www.netdoctor. co.uk/diseases/facts/lackofgrowthhormone.htm.
9. Parks JS, Felner EI. Hypopituitarism, In: Kliegman RM, Behrman RE, Jenson HB, Stanton BF, eds. Nelson Textbook of Pediatrics, 18th Ed, Philadelphia: Saunders Elsevier; 2007.p.2293.

10. Reiter EO, Rosenfeld RG. Normal and Aberrant Growth. In: Kronenberg HM, Melmed S, Polonsky KS, Larsen PR, editors. Williams Textbook of Endocrinology. 11th ed. Philadelphia, Pa: Saunders Elsevier;2008.p.321.

\section{How to cite this article?}

Devkota A, Upadhyay S. Growth Hormone Deficiency - A Case Report. J Nep Paedtr Soc 2011;31(2):134-136. 